This Journal is available in Telkom University online Journals

Jurnal Manajemen Indonesia

\title{
Predicting the Effects of Perceived Service Quality and Logistics Service Innovation on Repurchase Intention of Instant Courier Services through Customer Satisfaction and Trust
}

\author{
Kunthi A. Kusumawardani ${ }^{1}$ and Saras Asa Hastayanti ${ }^{2}$ \\ ${ }^{1,2}$ Faculty of Business, President University, Bekasi, Indonesia
}

\begin{abstract}
Logistics are not only playing a significant role in the business process, but they can also add value to the business, and even also determine the life of the firm. Due to its significance, the advancement of logistics is inevitable. Customers want everything faster, and they are even willing to pay more for the service. This study provides an empirical investigation of instant courier service customers in Indonesia. A total of 300 valid questionnaires were collected from the millennial that already had an experience in using Go-Send in greater Jakarta as a respondent and assessed using structural equation modelling (SEM). The results showed that perceived service quality influences customer satisfaction and trust. On the other hand, logistics service innovation influences perceived service quality but not customer satisfaction. While trust affects customer satisfaction and repurchase intention. Moreover, customer satisfaction influences repurchase intention. This study is one of the first to evaluate and confirm the relations of service quality-repurchase intention in instant courier service. This research contributes to the literature for future research in instant courier service by providing empirical evidence in Indonesia.
\end{abstract}

Keywords- Customer Satisfaction; Logistics Service Innovation; Perceived Service Quality; Repurchase Intention; Trust

\begin{abstract}
Abstrak
Logistik tidak hanya memainkan peran utama dalam proses bisnis, tetapi juga dapat menambah nilai bagi bisnis, dan bahkan juga menentukan kehidupan perusahaan. Karena signifikansinya, kemajuan logistik tidak dapat dihindari. Pelanggan menginginkan segalanya lebih cepat, dan mereka bahkan bersedia membayar lebih untuk layanan ini. Penelitian ini memberikan investigasi empiris pada pelanggan layanan kurir instan di Indonesia. Sebanyak 300 kuesioner yang valid dikumpulkan dari para milineal yang memiliki dalam menggunakan Gosend di Jakarta sebagai responden dan dinilai menggunakan Structural Equation Modelling (SEM). Hasil penelitian menunjukkan bahwa persepsi kualitas layanan mempengaruhi kepuasan dan kepercayaan pelanggan. Di sisi lain, inovasi layanan logistik memengaruhi persepsi kualitas layanan, tetapi bukan kepuasan pelanggan. Sementara, kepercayaan memengaruhi kepuasan pelanggan dan niat pembelian kembali. Selain itu, kepuasan pelanggan mempengaruhi niat pembelian kembali. Studi ini adalah salah satu yang pertama untuk mengevaluasi dan mengkonfirmasi hubungan niat pembelian kembali dengan kualitas layanan dalam layanan kurir instan. Kontribusi, implikasi praktis, dan batasan penelitian dibahas.s
\end{abstract}

Kata kunci- Customer Satisfaction; Logistics Service Innovation; Perceived Service Quality; Repurchase Intention; Trust

\section{INTRODUCTION}

Logistics is not only able to add value and becoming a vital factor in business activity, but also determine the success of a firm. The research on logistics has been conducted since the 1940s and focuses on mechanization 
(e.g., pallets and pallet lift) to improve the material handling process and to maximize space usage. However, the focus changed and widened in the 1950s with the development of intermodal transportation management (Robinson, 2018). Logistics nowadays has to become a massive industry with a revenue value of USD 8138.46 billion in 2015 and expected to be USD 15522.02 billion by 2023 (PRNewswire, 2016). The compound annual growth of all logistics segments from 2014 to 2018 is also showing a stable increase; postal delivery $0.6 \%$, air transport $2.1 \%$, sea transport $2.2 \%$, road transport $4.6 \%$, and rail transport 5.4\% (Statista Research Department, 2016).

The logistics industry is a big influence on a country's economic situation since it can improve the economy through many factors. It creates employment, generates national income, foreign investment influx, and increases the competitive capability of the corporation (Sezer \& Abasiz, 2017). For instance, in Indonesia, logistics play a crucial role in connecting the coffee farmers all over Indonesia to coffee shops in Bandung which benefitted both parties and developed their business (Anggadwita, Profityo, Permatasari, Alamanda, \& Hasfie, 2019). Many aspects have supported the logistics industry in Indonesia, for instance, population consumption, infrastructure development, and foreign investment. This resulted in a steady growth of the industry, as Frost \& Sullivan, an international consulting company predicted, there will be an increase of $15.4 \%$ by 2020 with the value of IDR 3.396 trillion (Motoris, 2018). Though the industry seems to show a flourishing development, logistics in Indonesia is still facing a crucial problem. According to the Ministry of Public Works and Housing of Republic Indonesia, the logistics costs are quite high, which reaches $24 \%$ of GDP, while other countries are below 15\% or even 10\% (Prabowo, 2019).

The logistics and E-commerce industry is supporting each other. On the one hand, logistics will help the ecosystem of E-Commerce, and on the other hand, with the massive development of E-Commerce, the logistics industry will be affected as well. E-Commerce growth in Indonesia is predicted to have a market value of USD 47,067 million by 2023 (Statista, 2019). With 195 million smartphone users in Indonesia and 30 active million shoppers, the potential growth is enormous and requires a new development of logistics (Bisara, 2019). One of the new trends which are currently on the rise in digitalization or also called smart logistics, which creates more convenience for the consumer and enables personalization for online order, payments, and even tracking (PWC, 2019). In Indonesia, many companies have embraced the new innovation, started from the big companies like DHL, JNE, and J\&T, and even startup companies like Ninja Express, Grab, and Gojek (Setyowati, 2018; Nabila, 2019).

The immense change in the logistics industry increased consumer expectation, get the goods faster, more flexibility, transparency, and low price (Tipping \& Kauschke, 2018). It reported that almost 25\% of young consumers are willing to pay more to get the product on the same day of the order or get an instant delivery (Joerss, Neuhaus, \& Schroder, 2016). Instant courier or same-day delivery is delivering the goods within few hours after the order has been made, and it has been the catalyst for online sales (Hausmann, Herrmann, Krause, \& Netzer, 2014). There are many players in instant courier services, for instance, Ninja Express, Deliveree, Gojek, and Grab. However, Gojek and Grab are the two giant online transportation companies that cause a threat to both existing and new players in the business of instant delivery due to their cheaper fee and massive resource of hundreds of thousands of drivers (Global Business Guide Indonesia, 2017). As for the overall value, Go-Jek has reached 50 trillion Rupiah with active riders of 1 million, and it is now spreading its wings on Vietnam. In contrast, Grab has achieved around more than 80 trillion Rupiah in the South East Asia market even before Uber acquisition with estimated active riders around 2 million (Paskalis, 2018). Although Grab has more valuation and active riders, in the local Indonesian market, Go-Jek is still dominating, as stated by Indonesian Business Competition Supervisory Commission (KPPU), the market share of Go-Jek reaches almost $80 \%$ (Aditiasari, 2018).

Instant courier delivery systems promised various features that can lead to an increase in perceived service quality, such as convenience, accuracy, and safety, which are loved by millennials generation (Sun, 2015). Supposedly they are delivering the services of the elements. However, dissatisfaction from the consumer comes from either product that does not arrive at the estimated time or product is damaged, and there is a connection between the improvement of operational performance and customer satisfaction (Bouzaabia, Bouzaabia, \& Capatina, 2013). Moreover, Indonesian Consumer Protection Foundation (YLKI) requests that the logistics service providers should guarantee that the items should have arrived safely to the customer because some crime cases through courier services, especially Go-Send, lead to the loss of goods delivered, even though the tracking system shows that the goods have been picked up by the courier and just waiting for the goods to arrive, but the item in question never arrived (Agung, 2017).

There are numerous studies on service quality that are based on the theory found by Parasuraman, Zeithaml, and Berry (1985). Studies on various logistics industry have also been done, for instance in manufacturers' satisfaction on logistic service (Saura, Frances, Contr1, \& Blasco, 2008), courier service (Vaalei, Rezaei, \& 
Shahijan, 2016), and third-party logistics outsourcing relationships (Juga, Juntunen, \& Grant, 2010). However, the study on service quality of same-day delivery service in logistics is still limited and has not been conducted in Indonesia. Thus, this study provides an insight into the importance of service quality in delivering customer satisfaction, which resulted in the customer repeat purchase. Furthermore, this research analyzes the influence of logistic service innovation, perceived service quality, customer satisfaction, and trust towards millennials' repurchase intention on instant courier services

This research consists of four sections. The first section begins with the explanation on the foundation of theoretical on logistic service innovation, perceived service quality, customer satisfaction, trust, and repurchase intention, which based on the previous studies. Section 2 explains the research model of the study, hypothesis, research design, and sampling methods. The third section discusses the result of the research, which includes validity, reliability, model fit, and hypothesis testing. Discussion from the finding, conclusion, and implication for further research are presented in the last section.

\section{HYPOTHESIS DEVELOPMENT}

\section{A. Perceived Service Quality}

Perceived service quality has been used by Parasuraman in 1988, which is comparing what customers expect and their perception after experiencing the service (Dlačić, Arslanagić, Kadić-Maglajlić, Marković, \& Raspor, 2014). Service quality or SERVQUAL has five dimensions of the concept, which are tangibility, reliability, responsiveness, assurance, and empathy (Parasuraman, Zeithaml, \& Berry, 1985). Another definition by Parasuraman (1985), service quality is highly determined by the expectation of the customer and their opinion of the service that is delivered (Noor \& Saad, 2016). A recent study regarding the perceived service quality stated that for the courier services dimensions of service quality is called "CouQual," which includes promptness, tangibility, accuracy, safety, and convenience (Vaalei, Rezaei, \& Shahijan, 2016). The promptness is a part of the service quality by Parasuraman (1985). It includes the responsiveness dimension of SERVQUAL (Brochado \& Pereira, 2017). Tangibility can be defined as one of the aspects of service quality that can be felt by the customers without them buy the services (Panda \& Das, 2014). Accuracy refers to the estimated time when it comes to courier services, either it is shorter or longer than the expected (Vaalei, Rezaei, \& Shahijan, 2016). Safety is a dimension that is constructed within the five SERVQUAL dimensions (Hussain, Al Nasser, \& Hussain, 2014). A convenience is a form of time and service efficiency by customers while buying products or enjoying the services (Roy, Shekhar, Lassar, \& Chen, 2018).

Service quality has played an essential role in marketing and logistics research, and it has been identified to successfully improved customer satisfaction as the critical key, this leads to repurchase intention of products or services (Saura, Frances, Contr1, \& Blasco, 2008). Service quality is one of the crucial factors to be discussed in compliance behaviour because it is related directly to customer satisfaction (Noor \& Saad, 2016). If the customers assess the after-consumption positively, it is more likely their satisfaction levels and their ability or availability to repurchase will increase (Han \& Hyun, 2015). SERVQUAL is being determined as one of the most effective measurements for examining service quality (Vaalei, Rezaei, \& Shahijan, 2016). The previous study about logistic service quality stated that service quality has a positive and significant link to customer satisfaction (Bouzaabia, Bouzaabia, \& Capatina, 2013).

A previous study in China regarding the e-retailing and its logistics showed that there is a strong relationship between service quality and the customer satisfaction in China e-retailing and logistics (Subramanian, Yu, Gunasekaran, \& Cheng, 2014). Perceived service quality has a direct influence on customer satisfaction on the user's intention to use transportation again (de Oña, de Oña, Eboli, Forciniti, \& Mazulla, 2016). A study about the Location Based Services (LBS) discussed when the services providers offer their services. The customer may put their trust and expectation of their satisfaction to those service providers (Wang \& Lin, 2016). Service delivery quality has a strong relationship with trust in gaining customers through e-banking services (Kao \& Lin, 2016).

\section{B. Logistic Service Innovation}

Logistics service innovation can go from the basic model one to more complex and can be applied in a range of internal operations and or service within business partners (Cichosz, Goldsby, Knemeyer, \& Taylor, 2017). The use of technologies such as RFID, EDI, and logistics programs such as managing vendor, cross-docking, etc. are part of logistics innovation, including the role of the entire logistics operation and its management (Grawe, 2009). The logistics innovation has been identified as a new kind of logistics service that is helpful for the related consumer (Flint, Larsson, Gammerlgaard, \& Mentzer, 2005). 
The overview of the recent research from the scholars has been researching the logistic services innovation. Their primary focus is on factors affecting the logistics service innovation. At the same time, there is also research regarding the logistic innovation model and path for the logistics services that are a critical part of online shopping transactions in the customer point of view and evaluation, thus impacting repurchase intention in e-commerce (Lin \& Zhang, 2015). Combining customers into the innovation process may increase the chance of customer satisfaction and improve the innovation performance of the logistics service (Cichosz, Goldsby, Knemeyer, \& Taylor, 2017). For logistic services, the more serious relations suggest higher client satisfaction, and fewer relationships suggest lower client satisfaction (Bellingkrodt \& Wallenburg, 2015). Service delivery is part of service innovation that impacting in customer behavioural intention, which includes the repurchase intention (Su, 2011; Bao, Li, Shen, \& Hou, 2016).

The previous study regarding the logistics innovation stated that the innovations of service would increase the performance of the service quality and its efficiency in developing new products (Rajahonka \& Bask, 2016). Furthermore, engaging the customers into the process of logistics service innovations could lead into intense customer satisfaction and increase the innovation of logistics service provider performance (Cichosz, Goldsby, Knemeyer, \& Taylor, 2017)

\section{Customer Satisfaction}

Customer satisfaction is a psychological feeling when the initial customer expectation and perceived performance meet in the centre, together with the customer needs' (Oliver, 1980). Satisfaction is defined as customers' affective response to the experience in doing online shopping transaction (Wallace, Gieses, \& Johnson, 2004). There are two different kinds of satisfaction, namely, satisfaction towards website and satisfaction towards the seller. When shopping online, the satisfaction of the site indicates the affective response of experience in doing online shopping. In contrast, the satisfaction towards the seller suggests the response of experience in doing the purchasing of products from the sellers (Wallace, Gieses, \& Johnson, 2004). According to Giese and Cote (2000), satisfaction is a reaction, whether it is emotional or cognitive. The response itself relates to specific interests such as desires, product or services, experience, and it happens at a particular time, such as after the decision, utilization, or accumulated experience (Cichosz, Goldsby, Knemeyer, \& Taylor, 2017).

According to Parasuraman (1985), the connection between the service quality standards and customer standards may deduct the gap of the service performance and increased the value of the service itself, which directly impacts on customer satisfaction (Kundu \& Datta, 2015). Previous research has been done in the internet service banking area. It stated that the customers are most likely satisfied when the service performance is beyond expected, and it makes the customer trust the service (Amin, 2016). In the context of customertechnology content interaction, showed that there is a strong connection between service quality and customer satisfaction (Orel \& A., 2014). The previous study has proven through the empirical data that the relationship between the experience of the customer's satisfaction and the repurchase intention have favourable action to it (Pappas, Pateli, Giannakos, \& Chrissikopoulos, 2014).

\section{Trust}

Trust has been defined as the beginning of the relationship, and as an exchange in several contexts, it is the core point of the relationship (Harris \& Goode, 2004). Trust also can be viewed as a set of confidence beliefs that can give a positive contribution of willingness to make a transaction in the online environment (Hart \& Dinev, T., 2006). Trust can be defined as an expectation that the others do not have, and the seller is providing the products as promised (Al-Debei, Akroush, \& Ashouri, 2015).

When a customer wants to make the repurchase decision, usually they do it because of their direct prior experience that they needed to choose whether they will do the repurchase intention with the same seller or not (Kim, 2008). Trust or distrust can be led from familiarity after product consumption, in which it is only in repurchase situations and can be considered as a major source of trust (Ba \& Pavlou, 2002). According to Mayer (1995), when the level of trust outperforms the limit of apparent risk, at that point, the trustor will participate in the risk-taking event such as repurchase decision (Fang, Qureshi, Sun, \& Mccole, 2015). The previous study about online retailer stated that the better service quality of a website influences the level of trust of a customer (Al-Debei, Akroush, \& Ashouri, 2015). In the online customer's case, trust decreases the barrier between uncertainty in repurchase intention and the risk (Bao, Li, Shen, \& Hou, 2016). Besides, Permatasari and Kartikowati (2018) suggested increasing the information design value and visual design to improve customer trust in e-commerce.

A consumer behavior study stated that consumers want satisfaction to be loyal to the seller or the service providers, and trust apparently becomes a part of customer satisfaction (Chinomona \& Dubihlela, 2014). The 
previous study by Teo and Liu (2007) said that trust decreases the risk and the uncertainty involved in doing the repurchase of products or services. It minimizes the gap between buyers and sellers and increases the chance of repurchase intention from the customers. Concluding that trust has a positive relationship with the repurchase intention (Bao, Li, Shen, \& Hou, 2016).

\section{E. Repurchase Intention}

Repurchase intention can be defined as a personal achievement of maintaining a relationship with the service provider and purchase the same service (Kitapci, Akdogan, \& Dortyol, 2014). The implication of repurchase intention has been evolving through years, and it is considered as a consumer behaviour outcome in which resulting in a high level of satisfaction and loyalty (Dlačić, Arslanagić, Kadić-Maglajlić, Marković, \& Raspor, 2014). Besides, repurchase intention has been known as a potential strategy for services marketing for maintaining the customers, less cost rather than attracting the new one, and more profitable for the long term (Saleem, Zahra, \& Yaseen, 2017). When a customer wants to make the repurchase decision, usually they do it because of their direct prior experience that needed to choose whether they will do the repurchase intention with the same seller or not (Kim, 2008). Customers who are satisfied tend to do the repurchase intention while the unsatisfied one will discontinue the use; this has been proved in previous research (Chiu, Lai, Chang, \& Hsu, 2012). Additionally, Permatasari and Kuswadi (2017) suggested maintaining the relationships with the customer in various ways, including via social media, to increase the company value and repurchase intention.

Service providers keep on using the resources to identify and utilize the number of factors that is related to repurchase intention, particularly service quality and customer satisfaction. Satisfaction is in the influencing factor of the repurchase intention (Chiu, Lai, Chang, \& Hsu, 2012). Service quality has played an essential role in marketing and logistics research, and it has been identified to successfully improve the customer satisfaction as the critical key in which leads to repurchase intention of products or services (Saura, Frances, Contrı, \& Blasco, 2008). In the repurchase intention context, trustworthiness has been identified as a direct transaction between sellers and buyers in which the buyers able to re-examine it by experience-based and acknowledge the sellers by their trustworthiness (Fang, Qureshi, Sun, \& Mccole, 2015). Expectation Confirmation Theory (ECT) in their context of marketing strategy stated that customer satisfaction is a crucial variable for customers' repurchase intention (Pappas, Pateli, Giannakos, \& Chrissikopoulos, 2014).

Based on the above explanation in this conceptual framework, the following hypotheses and research framework are as follow:

H1: Perceived Service Quality significantly influences customer satisfaction

H2: Perceived Service Quality significantly affects trust

H3: Logistics service innovations significantly influences Perceived Service Quality

H4: Logistics service innovations significantly influence customer satisfaction.

H5: Trust significantly affects customer satisfaction.

H6: Customer satisfaction significantly influences repurchase intention.

H7: Trust significantly influences repurchase intention.

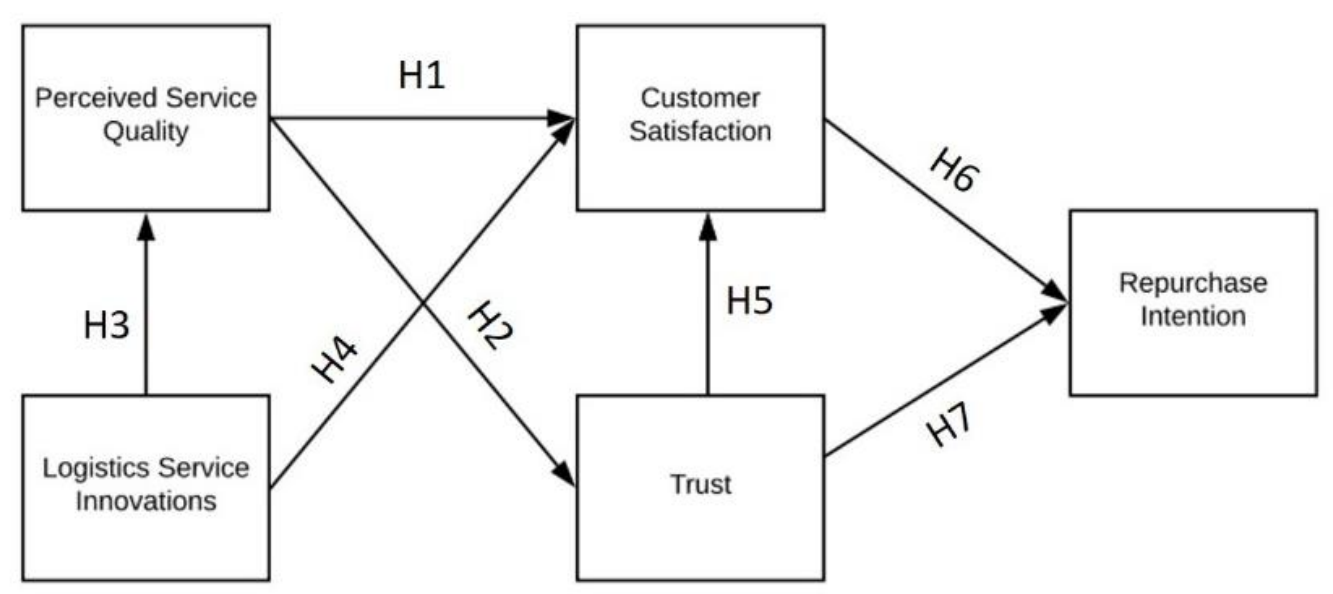

Figure 1. Research Framework (Source: Chou, 2014; Lin and Zhang, 2015; Vaalei, Rezaei, and Shahijan, 2016. 


\section{RESEARCH METHODS}

\section{A. Research Design}

This research is conducted to observe the millennial's repurchase intention towards instant courier services in greater Jakarta. The logistics service innovation is the independent variable. The perceived service quality, customer satisfaction, and trust are the mediating variables, while the repurchase intention is the dependent variable. Operational definition of variables consists of several questions and combined with being a construct measurement. From the dependent variable, which is repurchase intention, the mediating are perceived service quality and its dimensions (promptness, accuracy, safety, tangibility, and convenience), customer satisfaction, trust, and the last one is the independent variable, logistics service innovation. Each variable has five items of measurement, exclude the perceived service quality because the dimension each has five items of measurement, which make a total of 35 item measurements are made for this research.

This research is using an online-based questionnaire as a platform to collect all the data needed. Even though the online-based questionnaire can be wrongly targeted, however, it can be filtered through a screening question. The screening question is made in the first section or at the beginning of a questionnaire in order to examine whether the respondents are qualified or eligible to be a part of the research (FluidSurvey Team, 2013). If the respondent has answered "true" to the screening questions, means that the respondents are qualified for this research and may continue to the next question which is related to demographic such as age, gender, school, salary and after that have to fill the questions related with the variables. The questionnaire shared with other people via social media.

The questionnaire is adapting the 6-Point Likert Scale, which 1 represents "Strongly Disagree," and 6 represents "Strongly Agree." The reason for using a 6-point Likert Scale is because it is suitable for research that used several variables, and it does not have so many numbers of items that will burden the respondents (Chomeya, 2010). Not only make it more valid and reliable, but the 6-Point Likert Scale also helps the researcher to make the respondents commit to either positive or negative choice (Gwinner, 2011). The 6-point Likert scale consists of "Strongly Disagree," "Moderately Disagree," "Slightly Disagree," "Slightly Agree," "Moderately Agree," and "Strongly Agree" (Brown, 2010). Since this research is using the Structural Equation Model (SEM), the statistical software is used to get a descriptive analysis of the data (University of South Australia, 2018). Structural Equation Model (SEM) is used to show the causal relationships between variables. Besides, SEM is mostly used for a study that is designed to confirm a research design, which means that the research is focused on the strength of the relationships between each variable in a hypothesis (Devault, 2018).

\section{B. Population and Sampling}

The population is every complete group with at least one thing in common of characteristics within that group (Australian Bureau Statistics, 2018), and for this research, the population is the people who live in greater Jakarta. The sample of this research is being determined only for millennials. Millennials are people who were born in 1980 to the mid of 1990s or even early 2000 (Johnstone, 2018) and already had an experience in using Go-Send in greater Jakarta. These criteria are made in order to fulfil the requirements of this research. As for the sampling techniques, this research is using non-probability sampling because it is non-randomized methods to collect the sample. The minimum size of the sample of 200 and 300 respondents is recommended to perform a significant analysis, especially in assessing the consumerism and buying behaviour (Malhotra, 2010; Pallant, 2010; Gbadamosi, 2016). The questionnaires that were given to the respondents were 400 questionnaires. After five days of spreading the questionnaires, the researcher gathered around 380 respondents, but the valid respondents were 300 .

The questionnaire is from the previous researcher but disseminated through Google Form, which makes it easier to spread widely to get the sample. It was spread using a link through Instant Messenger such as WhatsApp, Line, and through social media like Instagram, Facebook, and Twitter. Furthermore, the respondents are also able to share the link to their contacts to fill the questionnaire as well. After the data is collected, it was downloaded in excel format from Google Form and then exported into the statistical software to analyze the validity, reliability, and AMOS for the hypothesis testing. 
Table 1. Sample Characteristic $(\mathrm{N}=300)$

\begin{tabular}{|c|c|c|c|c|}
\hline & & Characteristic & Frequency & Percent \\
\hline \multirow[t]{4}{*}{1} & Age & $18-20$ & 61 & $20.33 \%$ \\
\hline & & $21-25$ & 222 & $74.00 \%$ \\
\hline & & $25-30$ & 11 & $3.67 \%$ \\
\hline & & $30-28$ & 6 & $2.00 \%$ \\
\hline \multirow[t]{4}{*}{2} & Occupation & Employee & 210 & $70 \%$ \\
\hline & & Freelancer & 71 & $23.67 \%$ \\
\hline & & Entrepreneur & 14 & $4.67 \%$ \\
\hline & & Others & 5 & $1.66 \%$ \\
\hline \multirow[t]{4}{*}{3} & Income & $<$ IDR 1.000 .000 & 58 & $19.33 \%$ \\
\hline & & IDR $1.000 .000-5.000 .000$ & 190 & $63.33 \%$ \\
\hline & & IDR 5.000.000 - 10.000.000 & 41 & $13.67 \%$ \\
\hline & & > IDR 10.000.000 & 11 & $3.67 \%$ \\
\hline \multirow[t]{4}{*}{4} & $\begin{array}{l}\text { Instant Courier Service Use } \\
\text { Frequency }\end{array}$ & More than once a month & 76 & $25.33 \%$ \\
\hline & & Once a month & 96 & $32.00 \%$ \\
\hline & & Once within 3 months & 68 & $22.67 \%$ \\
\hline & & Once within 6 months & 60 & $20.00 \%$ \\
\hline \multirow[t]{4}{*}{5} & $\begin{array}{l}\text { Reason using instant courier } \\
\text { service }\end{array}$ & Personal Needs & 170 & $56.7 \%$ \\
\hline & & Online Shopping & 111 & $37.00 \%$ \\
\hline & & Professional Needs & 16 & $5.3 \%$ \\
\hline & & Others & 3 & $1.00 \%$ \\
\hline
\end{tabular}

\section{Data Analysis}

Descriptive analysis is strict only to a particular group of populations observed, and the data that is being described is only for a certain group. In contrast, the inferential analysis is being analyzed by statistical tests in order to see the instruments that are being observed happen due to intervention or chance (University of Minnesota, 2018). Validity can be defined as a measurement in the quantitative study to prove which concept is accurate in the research; there are two types of construct validity, which are convergent and discriminant validity (Heale \& Twycross, 2015). Convergent validity is supported if correlations between variables are high or significant, while the discriminant validity is supported if correlations between variables are low or not significant (Nova Southeastern University, 2018). When using statistical software, three criteria needed to be passed. The KMO-MSA \& Bartlet test should be $(\geq 0.5)$; communalities extraction should be greater than 0.5 , and the Total Variance should be at least $60 \%$ (Anastasiadou, 2011). The reliability test is used to measure the consistency of the variables being measured (Ye, Abbas, Hussain, \& He, 2018). The current research stated that internal consistency is defined by alpha, and if the score is close to 1 , the construct is reliable or if the Cronbach's Alpha 0.762, then the instrument is reliable (Heale \& Twycross, 2015).

As this research is using statistical software, there are several factors of analysis of the statistical software to be used. The C-MIN should be lower than 5, the RMSEA should be smaller than 0.08, the IFI, TLI, CFI should be higher or equal to 0.9, and the last one AGFI, GFI should be higher or equal to 0.8 to fulfil the requirement of Model Fit in statistical software (Shadfar \& Malekmohammadi, 2013). Meanwhile, for the hypothesis, to be 
accepted p-value should be less than 0.05 ( $\mathrm{p}<0.05)$, and the critical ratio should be higher than 1.96 (Abedi, Rostami, \& Nadi, 2015).

\section{RESUlt AND DisCUSSION}

\section{A. Construct Validity}

To test the validity of the data, the KMO (Kaiser-Meyer-Olkin) and Bartlett were used to test the validity (Sarstedt \& Mooi, 2014). The KMO for the independent variable and mediating variable, which are Logistics Service Innovations and Perceived Service Quality, is 0.906, which means it is accepted because the KMO criteria should be higher or equal to 0.5. Moreover, the Bartlett result is showing the significant value of 0.000 , where the Bartlett criteria should be lower or equal to 0.05. The Total Variance Explained (TVE) value is 67.928 or $67.9 \%$, where the TVE should be higher or equal to $60 \%$ (Hair, Black, Babin, \& Anderson, 2014). The Communalities Value for the independent variables is above 0.4. The same thing goes to Rotated Component Matrix; all the values for the independent variables are higher than 0.4 . Therefore, based on the criteria above for the validity of the Logistic Service Innovations and Perceived Service Quality are valid. The result of the validity test of the independent and mediating variable can be seen in Table 2 .

As for the dependent and mediating variable, which are Customer Satisfaction, Trust, and Repurchase Intention, the KMO value is 0.949 whereas the KMO criteria should be higher or equal to 0.5, while the Bartlett result is showing the significant value of 0.000 , where the Bartlett criteria should be lower or equal to 0.05. The Total Variance Explained for the dependent variable is showing the value of $72.563 \%$. The Communalities Value and Rotated Component Matrix both are exceeding 0.4. Therefore, both the mediating variable and dependent are valid. The result of the validity test of the dependent variable can be seen in Table 2 .

For the reliability test, since this research is using a statistical tool to process the data. The Cronbach's $\alpha$ is being used as the basis to get the reliability data. Here, the result shows that all the variables are exceeding the criteria value, which is 0.762 . The perceived service quality got 0.886 for the Cronbach's $\alpha$, the logistics service innovations Cronbach's $\alpha$ value is 0.869 , customer satisfaction got 0.907 , while trust got 0.871 and the last one, repurchase intention got 0.909 for its Cronbach's $\alpha$. Through this data, it can be concluded that all the variables are passing the reliability standard. The result of both validity and reliability tests of all variables can be seen in Table 2.

Table 2. Validity and Reliability Test Results

\begin{tabular}{|c|c|c|c|c|c|}
\hline Factor & $\begin{array}{l}\text { KMO and } \\
\text { Bartlett's } \\
\text { Test }\end{array}$ & $\begin{array}{l}\text { Rotated } \\
\text { Component } \\
\text { Matrix }\end{array}$ & Communalities & $\begin{array}{l}\text { Total } \\
\text { Variance } \\
\text { Explained }\end{array}$ & Reliability \\
\hline Perceived Service Quality & $.906 ; .0001$ & .602 & .517 & 67.928 & 0.886 \\
\hline PSQ11 & & .747 & .663 & & \\
\hline PSQ12 & & .795 & .720 & & \\
\hline PSQ13 & & .786 & .641 & & \\
\hline PSQ14 & & .809 & .686 & & \\
\hline PSQ15 & & .826 & .701 & & \\
\hline Logistic Service Innovation & & .830 & .726 & & 0.869 \\
\hline LSI2 & & .850 & .779 & & \\
\hline LSI3 & & .828 & .731 & & \\
\hline LSI4 & & .731 & .629 & & \\
\hline Customer Satisfaction & $.949 ; .0001$ & .731 & .712 & 72.563 & 0.907 \\
\hline $\mathrm{CS} 2$ & & .798 & .785 & & \\
\hline CS3 & & .714 & .708 & & \\
\hline
\end{tabular}




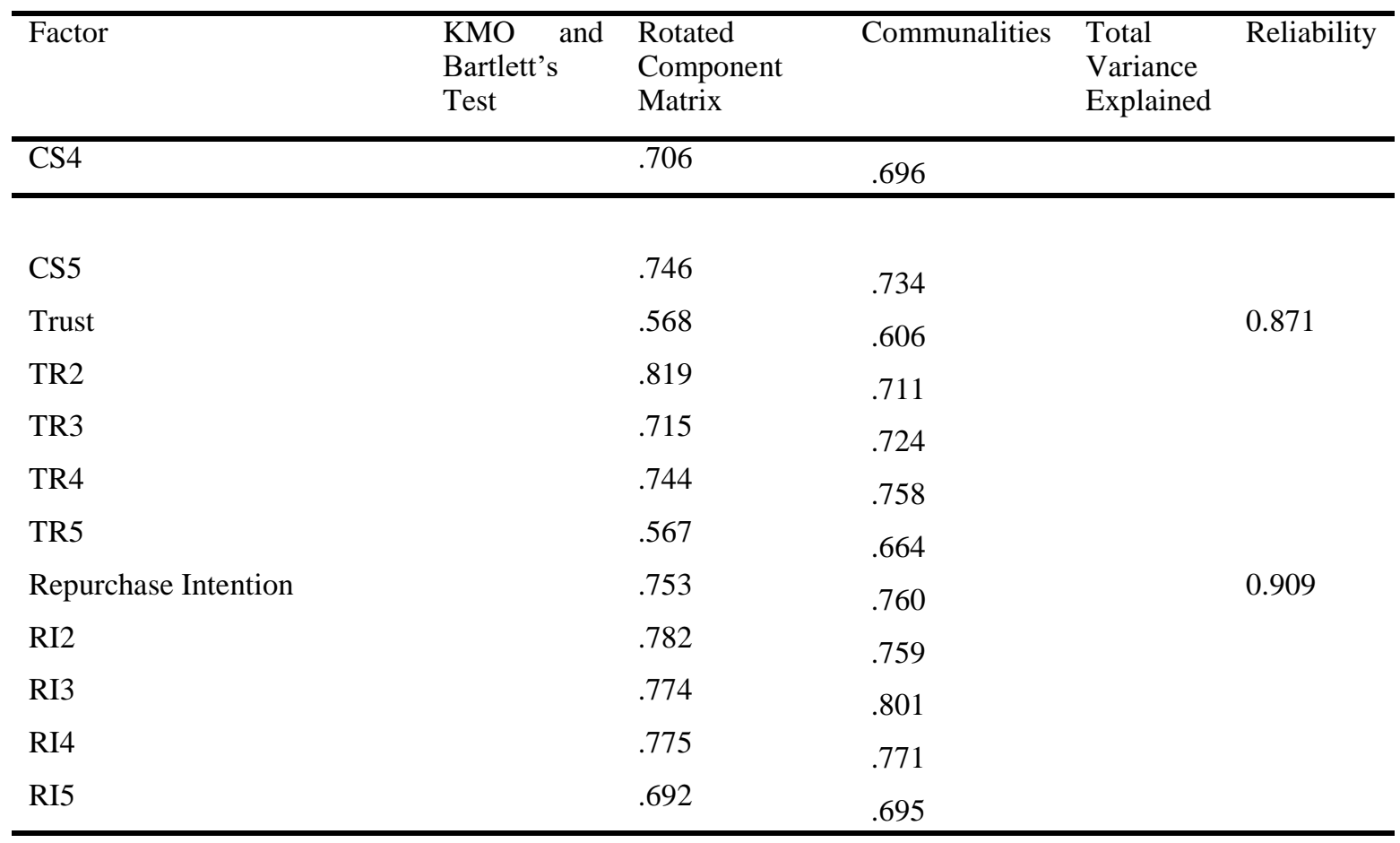

\section{B. Structural Model}

After all measurement models have been indicated valid and reliable, the next step is to analyze the structural model. In testing the structural model, model fit and its indices, along with the structural relationship, and hypothesis testing are conducted. Based on Table 3, the overall model fit for the research is a good model. It can be indicated through the RMSEA value, which is 0.057 , and it is lower than 0.08 . The CMIN/DF yields a value of 1.969, which is lower than 5.0. The IFI, TLI, CFI are .954, .945, .953 which exceed 0.9. The last one, AGFI, with the value of .848 and GFI with the value of .880 , the values exceed the criteria, which is 0.8 or higher. Therefore, the test suggests that the model is a good fit to the data.

Table 3. Model Fit and Quality Indices

\begin{tabular}{|c|c|c|c|}
\hline Model Fit Criteria & Cut-Off Criteria* & Research Result & Interpretation \\
\hline Chi-Square & 0.005 & .000 & Significant \\
\hline CMIN/DF & $\leq 5.00$ & 1.969 & Good Fit \\
\hline Tucker Lewis Index (TLI) & $0 \leq \mathrm{x} \leq 1$ & .945 & Good Fit \\
\hline Comparative fit Index (CFI) & $0 \leq \mathrm{x} \leq 1$ & .953 & Good Fit \\
\hline Normed Fit Index (NFI) & $0 \leq \mathrm{x} \leq 1$ & .910 & Good Fit \\
\hline Inferential Fix Index (IFI) & $0 \leq x \leq 1$ & .954 & Good Fit \\
\hline $\begin{array}{l}\text { Root Mean Square } \\
\text { Approximation }(\text { RMSEA) }\end{array}$ & $0.05 \leq \mathrm{RMSEA} \leq 0.1$ & .057 & Good Fit \\
\hline Goodness of Fit Index (GFI) & $0.5 \leq \mathrm{GFI} \leq 1$ & .880 & Good Fit \\
\hline Adjusted GFI (AGFI) & $0.5 \leq \mathrm{AGFI} \leq 1$ & .848 & Good Fit \\
\hline
\end{tabular}

*Source: Hair, Babin, Anderson, and Black (2018)

\section{Hypothesis Testing}

Once the model fit has been tested, the next step is to evaluate the structural relationships and also hypothesis testing. As for the hypothesis, it is being accepted if the p-value is less than 0.05 and the critical ratio 
is more than 1.96 (Hair, Babin, Anderson, \& Black, 2018), the research result can be seen in Table 4. H1 demonstrating a positive relationship of perceived service quality and customer satisfaction was supported with a CR value of 2.921and a standard error of 0.0001 . H2 is indicating a positive influence of perceived service quality towards trust (CR: 10.456, p-value < 0.001) as well as H3 proposing the significant influence of logistics service innovations towards perceived service quality (CR: 8.512, p-value < 0.001) were supported. Additionally, H5 showed the significant influence of trust towards customer satisfaction is supported (CR: 5.483, p-value < 0.001). The same result also showed by H6, which proposed a significant influence of customer satisfaction towards repurchase intention (CR: 5.641, p-value $<0.001)$, as well as H7 which indicated the significant influence of trust towards repurchase intention (CR: 3.736, p-value < 0.001) were both supported. Interestingly, $\mathrm{H} 4$ proposing the influence of logistics service innovations towards customer satisfaction (CR: 8.512 , p-value $<0.001$ ) was not supported.

Table 4. Hypothesis Testing

\begin{tabular}{llccc}
\hline Hypothesis & \multicolumn{1}{c}{ Path } & C.R. & P-Value & Interpretation \\
\hline H1 & $\begin{array}{l}\text { Perceived Service Quality } \rightarrow \text { Customer } \\
\text { H2 }\end{array}$ & 2.921 & .003 & Supported \\
H3 & Perceisfaction & & & \\
& Logistics Service Innovations $\rightarrow$ Perceived & 8.512 & $* * *$ & Supported \\
H4 & Service Quality & & & \\
& Logistics service innovations $\rightarrow$ Customer & 1.141 & .254 & Not Supported \\
H5 & Satisfaction. & & & \\
H6 & Trust $\rightarrow$ Customer Satisfaction. & 5.483 & $* * *$ & Supported \\
H7 & Customer satisfaction $\rightarrow \quad$ Repurchase & 5.641 & $* * *$ & Supported \\
& Intention. & & & Supported \\
& Trust $\rightarrow$ Repurchase Intention. & .102 & 3.736 & Supported \\
\hline
\end{tabular}

\section{Discussion}

Based on the hypothesis testing that has been done, a total of six hypotheses are accepted or have significantly influenced the variable. At the same time, there was one hypothesis not accepted or has no significant influence on the variable. The first hypothesis of this research is "there is a significant influence of perceived service quality towards customer satisfaction." Based on the hypothesis testing, it shows that the perceived service quality has significantly influenced customer satisfaction. This hypothesis result is being supported by Subramanian, Gunasekaran, Yu, Cheng, \& Ning (2014) that there is a strong relationship between perceived service quality and customer satisfaction. Also, this hypothesis is supported by de Oña, de Oña, Eboli, Forciniti, \& Mazulla (2016), who stated perceived service quality directly positively influenced customer satisfaction. Furthermore, the overall service quality and its overall dimensions, such as promptness, convenience, tangibility, accuracy, and safety of Go-Send services, have been proven to influence customer satisfaction. For example, e-commerce has teamed up with Go-Send to increase value for e-commerce like Lazada and make it easier for the customer (Maulana, 2016).

The second hypothesis is "there is a significant influence of perceived service quality towards trust." Based on hypothesis testing, the second hypothesis is accepted, and it means that perceived service quality has significantly influenced the trust. The study by Wang and Lin (2016) showed that the perceived service quality has positively influenced the trust. Another study by Kao and Lin (2016) also stated that perceived service quality directly influenced trust. The third hypothesis is "there is a significant influence of logistics service innovations towards perceived service quality." The third hypothesis is accepted, and it means that the logistics service innovations have significantly influenced the perceived service quality. This hypothesis is being supported by a study from Rajahonka and Bask (2016), stated that the innovations of service increased the performance of service quality and its efficiency. The logistic service innovation that instant courier service providers used, such as the live tracker, has influenced the service performance and its service quality to support the delivery (Agung, 2017).

The fourth hypothesis is "there is a significant influence of logistics service innovations towards customer satisfaction." Based on the hypothesis testing, this hypothesis is rejected because the critical ratio is less than 
1.96, and the p-value is more than 0.05 , which is 0.254 . This hypothesis is supported by a study by Fatkhurrohman (2011). The study found that service innovation did not directly influence customer satisfaction. Another study by Lee (2012), stated that there is no direct relationship between service innovation and customer satisfaction. There is a case regarding logistics service innovations, and it is related to customer satisfaction. One of the logistic service innovations that instant courier providers offer is the live tracker, where the customer can track the courier through the application. Some crime cases through courier services, and lead to the loss of goods delivered. Even though the tracking system shows that the goods have been picked up by the courier, the item never arrives (Agung, 2017).

The fifth hypothesis is "there is a significant influence of trust towards customer satisfaction." From the hypothesis testing result, this hypothesis is accepted and means that trust has significantly influenced customer satisfaction. A supporting study from Chinomona and Dubihlela (2014) stated that trust is influencing customer satisfaction and becomes part of it. To increase the customer satisfaction level, instant courier service providers have joined with several small and medium-sized enterprises through iSeller, where it can reach the customers who want to buy from a small retailer with instant delivery services (Sutriyanto, 2018). The sixth hypothesis is "there is a significant influence of customer satisfaction towards repurchase intention." From the hypothesis testing result, this hypothesis is accepted and means that customer satisfaction has significantly influenced the repurchase intention. A supporting study from Pappas, Pateli, Giannakos, \& Chrissikopoulos (2014) stated that there is a strong relationship between customer satisfaction and repurchase intention. The last hypothesis is "there is a significant influence of trust towards repurchase intention." Based on the hypothesis testing result, this hypothesis is accepted, and it means that trust has significantly influenced the repurchase intention. The hypothesis has been supported by a study from Teo and Liu (2007), stated that trust had minimized the gap between buyers and sellers, and it is influencing the chance to repurchase. Furthermore, the study from Li., Shen, \& F. (2016) concluding that trust has a positive relationship with the repurchase intention. Go-Send is also having some kind of promotion through Go-Points, which the customer can enjoy the promotion, and it will be announced weekly for the benefits, which drives the customer to use Go-Send more frequently to get the benefits (Haryanto, 2018).

\section{CONCLUSION}

The research analyzed the factors influencing customers in having repurchase intentions in instant courier service among millennials. The result indicated the importance of several factors in repurchase intention, namely perceived service quality, logistics service innovation, trust, and customer satisfaction. Out of 7 hypotheses, there was only one hypothesis not supported. The hypotheses that are accepted are; There is a significant influence of perceived service quality towards customer satisfaction (H1), there is a significant influence of perceived service quality towards trust $(\mathrm{H} 2)$, there is a significant influence of logistics service innovations towards perceived service quality (H3), there is a significant influence of trust towards customer satisfaction (H5), there is a significant influence of customer satisfaction towards repurchase intention (H6), and there is a significant influence of trust towards repurchase intention (H7). Meanwhile, the rejected hypothesis is there is a significant influence of logistics service innovations on customer satisfaction (H4). Furthermore, this research provides an insight into the importance of instant courier service both in business and also academic research through recommendations.

\section{A. Business Implication}

Based on the findings, there are two challenges faced by the instant courier service provider. The first one is to deliver customer satisfaction through service quality. Perceived service quality remains a crucial factor in influencing both trust and customer service, which leads to repurchase intention. There are several approaches that instant courier service providers can take to improve the perceived service quality. Firstly, the instant courier provider should offer and guarantee the safety of the package. Customer safety perception has been proven as a crucial factor in delivering customer satisfaction in the service industry (Rathert, May, \& Williams, 2011). To improve safety, instant courier providers should ensure the customer that their packages will be delivered in perfect shape without any defect. Thus, the instant courier service providers could install a box for the package instead of using a bag in their bikes, the box that is being used in food delivery so that the fragile stuff can be delivered safely.

Furthermore, the research found that logistics service innovation does not influence customer satisfaction has been proven by several accidents of undelivered packages even though the customer can access the live tracker. 
Therefore, the instant courier service provider should give the customer more assurance to reduce customer perceived risk. Hence, logistics service innovation should not only on the technology aspect or, in this case, the live tracker, but also other factors that may increase the continuous satisfaction. So and Sculli (2002) mentioned that providing more assistance, for instance, the ability to speak to a customer service representative for help or money-back guarantee is the possible solution for the company to build trust and even make the business sustainable. Moreover, McDoughall, Levesque, and Vanderplaat (1998) also stated that in-service guarantees, customers prefer to have a specific warranty when they consider invoking it due to its clarity and manifest nature.

Also, with the advanced and robust development of E-commerce, the opportunity of the instant courier service providers to grow is tremendous. Therefore, the instant courier service provider should also consider in business expansion, and provide the service not only in big cities in the country. The development of business may lead to many positive effects, for instance, to give the impression of higher financial viability of the company, generate more sales, influence market price, and reduce competition risk (Invest Northern Ireland, 2019). Likewise, strong cooperation with E-commerce businesses is also highly recommended. Instant courier service providers should cooperate with the related e-commerce for the delivery system to set a standard if there is a sudden increase of order so that it is manageable for everyone, such as real-time tracking for sellers and buyers (Fajrian, 2017).

\section{B. Future Research}

Many factors are influencing the repurchase intention of customers. This study suggests future research to add other factors for the perceived service quality or change it into logistic service quality because this research proposed the dimension of perceived service quality such as promptness, safety, accuracy, convenience, and tangibility while there are other dimensions of logistic service quality such as timeliness, condition/accuracy of the order placed, information quality, and availability/quality of the courier personnel have been specified for the logistics services provider context (Chou, 2014). Due to limitations from this research, future research can also adopt more from other research. While this research focuses more on customer loyalty antecedents such as trust and perceived service quality, the future researcher may add new variables such as brand image and perceived value (Aydin \& Özer, 2005). Moreover, this research only examined greater Jakarta. It is suggested that the future researcher can analyze the wider scope area or other instant courier services.

\section{REFERENCES}

Abedi, G., Rostami, F., \& Nadi, A. (2015). Analyzing the Dimensions of the Quality of Life in Hepatitis B Patientsusing Confirmatory Factor Analysis. Global Journal of Health Science, 7(7), 22-31.

Aditiasari, D. (2018, September 5). Data Ini Bilang Grab Jauh Tertinggal dari Go-Jek. Retrieved March 20, 2019, from Detik: https://inet.detik.com/business/d-4198221/data-ini-bilang-grab-jauh-tertinggal-dari-gojek

Agung, B. (2017, December 8). YLKI Minta GoSend Cs Jamin Barang Sampai ke Tangan Konsumen. Retrieved March 20, 2019, from CNN Indonesia: https://www.cnnindonesia.com/teknologi/20171208145545-185261098/ylki-minta-gosend-cs-jamin-barang-sampai-ke-tangan-konsumen

Al-Debei, M., Akroush, M. N., \& Ashouri, M. I. (2015). Consumer attitudes towards online shopping: The effects of trust, perceived benefits, and perceived web quality. Internet Research, 25(5), pp.707-733.

Amin, M. (2016). Internet banking service quality and its implication on e-customer satisfaction and e-customer loyalty. International Journal of Bank Marketing, 34(3), 280-306.

Anastasiadou, S. D. (2011). reliability and validity testing of a new scale for measuring attitudes toward learning statistics with technology. Acta Didactica Napocensia, 4(1), 1-10.

Anggadwita, G., Profityo, W. B., Permatasari, A., Alamanda, D. T., \& Hasfie, M. .. (2019). Analysis of Value Chain Model on Small and Medium Enterprises (SMEs): A Case Study of Coffee Shops in Bandung. 1st International Conference on Industrial and Manufacturing Engineering (pp. 1-8). Medan: IOP Publishing. doi:10.1088/1757-899X/505/1/012098 
Australian Bureau Statistics. (2018, November 1). Statistical language. Retrieved November 12, 2018, from http://www.abs.gov.au/websitedbs/a3121120.nsf/home/statistical+language+-+what+is+a+population

Aydin, S., \& Özer, G. (2005). The analysis of antecedents of customer loyalty in the Turkish mobile telecommunication market. European Journal of Marketing, 39(7/8), 910-925.

Ba, S., \& Pavlou, P. (2002). Evidence of the Effect of Trust Building Technology in Electronic Markets: Price Premiums and Buyer Behavior. Management information system research center, University of Minnesota, 26(3), 243-268.

Bao, H., Li, B., Shen, J., \& Hou, F. (2016). Repurchase intention in the Chinese e-marketplace: Roles of interactivity, trust and perceived effectiveness of e-commerce institutional mechanisms. Industrial Management and Data Systems, 116(8), 1759-1778.

Bellingkrodt, S., \& Wallenburg, C. M. (2015). The role of customer relations for innovativeness and customer satisfaction: A comparison of service industries. The international Journal of Logistic Management, 26(2), 254-274.

Bisara, D. (2019, February 5). Indonesia's E-commerce Market Larger Than Estimated; Consumer Habits Changing: Study. Retrieved September 20, 2019, from Jakarta Globe: https://jakartaglobe.id/context/indonesias-ecommerce-market-larger-than-estimated-consumer-habitschanging-study

Bouzaabia, R., Bouzaabia, O., \& Capatina, A. (2013). Retail Logistics Service Quality: A Cross-Cultural Survey On Customers Perception. International Journal of Retail \& Distribution Management, 41(8), 627-647.

Brochado, A., \& Pereira, C. (2017). Comfortable experiences in nature accommodation: Perceived service quality in Glamping. Journal of Outdoor Recreation and Tourism, 17, 77-83.

Brown, S. (2010, 12 11). Likert Scale Examples. Retrieved from Iowa State University Extension: https://www.extension.iastate.edu/documents/anr/likertscaleexamplesforsurveys.pdf

Chinomona , R., \& Dubihlela, D. (2014). Does Customer Satisfaction Lead to Customer Trust, Loyalty and Repurchase Intention of Local Store Brands? The Case of Gauteng Province of South Africa. Mediterranean Journal of Social Sciences, 5(9), 23-32.

Chiu, C. M., Lai, H., Chang, C.-H., \& Hsu, M.-H. (2012). Re-examining the influence of trust on online repeat purchase intention: The moderating role of habit and its antecedents. Decision Support System, 53(4), 835-845.

Chomeya, R. (2010). Quality of Psychology Test Between Likert Scale 5 and 6 Points. Journal of Social Sciences, 3(6), 399-403.

Chou, P.-F. (2014). An Evaluation of Service Quality, Trust, and Customer Loyalty in Home-Delivery Services. International Journal of Research In Social Sciences, 3(8), 99-108.

Cichosz, M., Goldsby, T. J., Knemeyer, A., \& Taylor, D. F. (2017). Innovation in Logistics Outsourcing Relationship - in the Search of Customer Satisfaction. Scientific Journal of Logistics, 13(2), 209-219.

de Oña, J., de Oña, R., Eboli, L., Forciniti, C., \& Mazulla, G. (2016). Transit passengers' behavioural intentions: the influence of service quality and customer satisfaction. Transportmetrica A: Transport Science, 12(5), $385-412$.

Devault, G. (2018, September 12). Structural Equation Modeling (SEM). Retrieved November 11, 2018, from Small Business - Market Research: https://www.thebalancesmb.com/quantitative-research-usingstructural-equation-modeling-2297146

Dlačić, J., Arslanagić, M., Kadić-Maglajlić, S., Marković, S., \& Raspor, S. (2014). Exploring perceived service quality, perceived value, and repurchase intention in higher education using structural equation modelling. Total Quality Management \& Business Excellence, 25(1-2), 141-157.

Fajrian. (2017, 12 13). Respons Gojek soal Keluhan Gosend. Retrieved 2 5, 2019, from CNN Indonesia: https://www.cnnindonesia.com/teknologi/20171031141656-188-252416/respons-gojek-soal-keluhangosend 
Fang, Y., Qureshi, I., Sun, H., \& Mccole, P. (2015). Trust, Satisfaction, and Online Repurchase Intention: The Moderating Role of Perceived Effectiveness of E-commerce Institutional Mechanism. MIS Quarterly Research Article, 38(2), 407-427.

Fatkhurrohman, M. D. (2011). The Effect of Innovation Factors to Customers Loyalty by Structural Equation Model. International Journal of Economics and Management Engineering, 5(4), 370-374.

Flint, D. J., Larsson, E., Gammerlgaard, B., \& Mentzer, J. T. (2005). Logistics innovation: a customer valueoriented social process. Journal of business logistics, 26(1), 113-147.

FluidSurvey Team. (2013, September 3). Screening Question. Retrieved October 18, 2018, from Fluid Survey: http://fluidsurveys.com/university/screening-questions/

Gbadamosi, A. (2016). Handbook of Research on Consumerism and Buying Behavior in Developing Nations. Hershey, PA: Business Science Reference.

Global Business Guide Indonesia. (2017). Indonesia's Courier and Delivery Service Sector: E-commerce a Major Growth Driver. Retrieved September 20, 2019, from Global Business Guide Indonesia: http://www.gbgindonesia.com/en/services/article/2017/indonesia_s_courier_and_delivery_service_sector _e_commerce_a_major_growth_driver_11807.php

Grawe, S. J. (2009). Logistics innovation: a literature-based conceptual framework. The International Journal of Logistics Management, 20(3), 360-377.

Gwinner, C. (2011, January 20). Retrieved October 20, 2018, from Infosurv: www.infosurv.com/wpcontent/uploads/2011/01/Likert_Scale_Debate.pdf

Hair, J. F., Babin, B. J., Anderson, R. E., \& Black, W. C. (2018). Multivariate Data Analysis (8th ed.). Andover, Hampshire: Cengage Learning, EMEA.

Hair, J. F., Black, W. C., Babin, B. J., \& Anderson, R. E. (2014). Multivariate Data Analysis (7th ed.). Harlow, Essex: Pearson Education Limited.

Han, H., \& Hyun, S. S. (2015). Customer retention in the medical tourism industry: Impact of quality, satisfaction, trust, and price reasonableness. Tourism Management, 46, 20-29.

Harris, L. C., \& Goode, M. H. (2004). The four levels of loyalty and the pivotal role of trust: a study of online service dynamics. Journal of Retailing, 80(2), 139-158.

Hart, P., \& Dinev, T. (2006). An extended privacy calculus model for e-commerce transactions. Information system research, 17(1), 61-80.

Haryanto, A. T. (2018, 9 19). Go-Points, Cara Go-Jek Tingkatkan Loyalitas Pengguna. Retrieved 0125,2019, from detikinet: https://inet.detik.com/cyberlife/d-4219455/go-points-cara-go-jek-tingkatkan-loyalitaspengguna

Hausmann, L., Herrmann, N.-A., Krause, J., \& Netzer, T. (2014, March). Same-day delivery: The next evolutionary step in parcel logistics. Retrieved September 20, 2019, from McKinsey \& Company: https://www.mckinsey.com/industries/travel-transport-and-logistics/our-insights/same-day-delivery-thenext-evolutionary-step-in-parcel-logistics

Heale, R., \& Twycross, A. (2015, August 10). Validity and reliability in quantitative studies. Retrieved November 2018, 14, from Research Gate: https://www.researchgate.net/publication/280840011_Validity_and_reliability_in_quantitative_research

Hikmatiar, I. (2019, February 6). Awas!! Modus Penipuan Oknum GO-SEND Same Day Ini Terjadi Pada Kamu. Retrieved September 20, 2019, from Irfan Hikmatiar: https://irfanhikmatiar.com/2019/02/06/penipuangosend-sameday/

Hussain, R., Al Nasser, A., \& Hussain, Y. K. (2014). Service quality and customer satisfaction of a UAE-based airline: An empirical investigation. Journal of Air Transportational Management, 42, 167-175.

Invest Northern Ireland. (2019, September 11). Should I grow my business? Advantages and disadvantages of growing your business. Retrieved October 4, 2019, from nibusinessinfo.co.uk: https://www.nibusinessinfo.co.uk/content/advantages-and-disadvantages-growing-your-business 
Joerss, M., Neuhaus, F., \& Schroder, J. (2016, October 19). How customer demands are reshaping last-mile delivery. Retrieved March 20, 2019, from McKinsey: https://www.mckinsey.com/industries/traveltransport-and-logistics/our-insights/how-customer-demands-are-reshaping-last-mile-delivery

Johnstone. (2018, May 25). GEN WHEN? Who are Millennials, Baby Boomers and Generation Z? Generation groups explained. Retrieved November 12, 2018, from The Sun: https://www.thesun.co.uk/fabulous/5505402/millennials-baby-boomers-generation-groups-Z-y-Xexplained/

Juga, J., Juntunen, J., \& Grant, D. B. (2010). Service quality and its relation to satisfaction and loyalty in logistics outsourcing relationships. Managing Service Quality, 20(6), 496-510.

Kao, T., \& Lin, W. T. (2016, April). The relationship between perceived e-service quality and brand equity. Computers in Human Behavior, 57, 208-218.

Kim, E. (2008). Trust and Satisfaction, Two Stepping Stones for Successful E-Commerce Relationships: A Longitudinal Exploration. Information system research, 20(2), 159-316.

Kitapci, O., Akdogan, C., \& Dortyol, I. T. (2014). The Impact of Service Quality Dimensions on Patient Satisfaction, Repurchase Intentions and Word-of-Mouth Communication in the Public Healthcare Industry. Procedia - Social and Behavioral Sciences, 148, 161-169.

Kundu, S., \& Datta, S. K. (2015). Impact of trust on the relationship of e-service quality and customer satisfaction. EuroMed Journal of Business, 10(1), 21-46.

Lee, B. C. (2012). The determinants of consumer attitude toward service innovation - the evidence of ETC system in Taiwan. Journal of Services Marketing, 26(1), 9-19.

Lin, D., \& Zhang, R. (2015). Research on the impact mechanism between logistics service innovation and online customer repurchase intention. International conference on management science and management innovation, 10, 629-635.

Malhotra, N. K. (2010). Marketing Research: An Applied Orientation (6th ed.). Upper Saddle River, NJ: Prentice Hall.

Maulana, A. (2016, Desember 04). Lazada Gandeng Gojek untuk Percepat Pengiriman . Retrieved from CNN Indonesia: https://www.cnnindonesia.com/teknologi/20160412171411-185-123411/lazada-gandenggojek-untuk-percepat-pengiriman

McDougall, G. H., Levesque, T., \& VanderPlaat, P. (1998). Designing the service guarantee: unconditional or specific? Journal of Services Marketing, 12(4), 278-293.

Motoris. (2018, May 7). Industri Logistik Indonesia Bernilai Rp 4.396 T di 2020. Retrieved September 18, 2019, from Motoris: https://www.motoris.id/industri/industri-logistik/9400/industri-logistik-indonesiabernilai-rp-4-396-t-di-2020/

Nabila, M. (2019, May 9). Ramai Beradu Teknologi Realisasikan “Smart Logistics”. Retrieved September 20, 2019, from DailySocial: https://dailysocial.id/post/smart-logistics-indonesia

Noor, A. M., \& Saad, R. A. (2016). The Impact of Attitude and Perceived Service Quality on Zakah Compliance Behavior: The Mediating Effect of Trust. International Soft Science Conference, 6(1), 376-381.

Nova Southeastern University. (2018, September 11). Class Help. Retrieved November 15, 2018, from Nova Southeastern University: http://www.cps.nova.edu/ cpphelp/class/psy0507/convergv.html

Oliver, R. L. (1980). Cognitive model of antecedents and concequences of satisfaction. Journal of Marketing Research, 17(4), 460-469.

Orel, F. D., \& A., K. (2014). Supermarket self-checkout service quality, customer satisfaction, and loyalty: Empirical evidence from an emerging market. Journal of Retailing and Customer Services, 21(2), 118129.

Pallant, J. (2010). SPSS Survival Manual: A step by step guide to data analysis using SPSS (4th ed.). Berkshire, UK: McGraw Hill.

Panda, T. K., \& Das, S. (2014). The Role of Tangibility in Service Quality and Its Impact on External Customer Satisfaction: A Comparative Study of Hospital and Hospitality Sectors. Journal of Marketing Management, 13(4), 53-69. 
Pappas, O., Pateli, A. G., Giannakos, M. N., \& Chrissikopoulos, V. (2014). Moderating effects of online shopping experience on customer satisfaction and repurchase intentions. International Journal of Retail and Distribution Management, 42(3), 187-204.

Parasuraman, A., Zeithaml, V. A., \& Berry, L. L. (1985). A Conceptual Model of Service Quality and Its Implications for Future Research. Journal of Marketing, 49(4), 41-50.

Paskalis, Y. (2018, March 27). Intip Peta Kekuatan Armada Go-Jek Versus Grab. Retrieved March 20, 2019, from Tempo: https://bisnis.tempo.co/read/1073905/intip-peta-kekuatan-armada-go-jek-versusgrab/full\&view=ok

Permatasari, A., \& Kartikowati, M. (2018). The influence of website design on customer online trust and perceived risk towards purchase intention: a case of $\mathrm{O} 2 \mathrm{O}$ commerce in Indonesia. International Journal of Business and Globalisation, 21(1), 74-86. doi:10.1504/IJBG.2018.094097

Permatasari, A., \& Kuswadi, E. (2017). The Impact of Social Media on Consumers' Purchase Intention: A Study of Ecommerce Sites in Jakarta, Indonesia. Review of Integrative Business and Economics Research, 1, 321-335.

Prabowo, D. (2019, February 27). Biaya Logistik Indonesia Masih Mahal. Retrieved September 19, 2019, from Kompas: https://properti.kompas.com/read/2019/02/27/230149621/biaya-logistik-indonesia-masih-mahal

PRNewswire. (2016, October 19). Global Logistics Market to Reach US\$15.5 Trillion by 2023; Research Report Published by Transparency Market Research. Retrieved September 18, 2019, from PRNewswire: https://www.prnewswire.com/news-releases/global-logistics-market-to-reach-us155-trillion-by-2023research-report-published-by-transparency-market-research-597595561.html

PWC. (2019). Five Forces Transforming Transport \& Logistics. Warsaw: PWC.

Rajahonka, M., \& Bask, A. (2016). The development of outbound logistics services in the automotive industry a logistics service provider's view. International Journal of Logistics Management, 27(3), 707-737.

Rathert, C., May, D. R., \& Williams, E. S. (2011). Beyond service quality: The mediating role of patient safety perceptions in the patient experienceYsatisfaction relationship. Health Care Manage Review, 36(4), 359368.

Robinson, A. (2018, April 5). The Evolution and History of Supply Chain Management. Retrieved September 13, 2019, from Cerasis: https://cerasis.com/history-of-supply-chain-management/

Roy, K. S., Shekhar, V., Lassar, W. M., \& Chen, T. (2018). Customer engagement behaviors: The role of service convenience, fairness and quality. Journal of Retailing and Customer Services, 44, 293-304.

Saleem, M. A., Zahra, S., \& Yaseen, A. (2017). Impact of service quality and trust on repurchase intentions - the case of Pakistan airline industry. Asia Pacific Journal of Marketing and Logistics, 29(5), 1136-1159.

Santhika. (2017, Desember 9). Ramai Dikeluhkan, Gojek Sempat Jelaskan Beda Layanan Gosend. Retrieved Oktober 1, 2018, from CNN Indonesia: https://www.cnnindonesia.com/teknologi/20171208165541-185261122/ramai-dikeluhkan-gojek-sempat-jelaskan-beda-layanan-gosend

Sarstedt, M., \& Mooi, E. (2014). A Concise Guide to Market Research: The Process, Data, and Methods Using IBM SPSS Statistics (2nd ed.). Berlin, Heidelberg: Springer Berlin Heidelberg.

Saura, I. G., Frances, D. S., Contr1, G. B., \& Blasco, M. F. (2008). Logistics service quality: a new way to loyalty. Industrial Management \& Data Systems, 108(5), 650-668.

Setyowati, D. (2018, August 14). Adu Kuat Perusahaan Logistik Berebut Pasar E-Commerce. Retrieved September 20, 2019, from KataData: https://katadata.co.id/berita/2018/08/14/adu-kuat-perusahaanlogistik-berebut-pasar-e-commerce

Sezer, S., \& Abasiz, T. (2017). THE IMPACT OF LOGISTICS INDUSTRY ON ECONOMIC GROWTH: AN APPLICATION IN OECD COUNTRIES. Eurasian Journal of Social Sciences, 5(1), 11-23.

Shadfar, S., \& Malekmohammadi, I. (2013). Application of Structural Equation Modeling (SEM) restructuring state intervention toward paddy production development. International Journal of Academic Research in Business and Social Sciences, 3(12), 576-618. 
Showkat, N., \& Parveen, H. (2017, July 20). Non-Probability and Probability Sampling. Retrieved November 14, 2018, from Research Gate: https://www.researchgate.net/publication/319066480_NonProbability_and_Probability_Sampling

So, M. W., \& Sculli, D. (2002). The role of trust, quality, value and risk in conducting e-business. Industrial Management \& Data Systems, 102(9), 503-512.

Statista. (2019). eCommerce report 2019. Hamburg: Statista Digital Market Outlook.

Statista Research Department. (2016, October 18). Compound annual growth rate (CAGR) of the logistics industry from 2014 to 2018, by segment. Retrieved September 18, 2019, from Statista: https://www.statista.com/statistics/943517/logistics-industry-global-cagr/

$\mathrm{Su}$, C.-S. (2011). The role of service innovation and customer experience in ethnic restaurants. The Service Industries Journal, 31(3), 425-440.

Subramanian, N., Yu, J., Gunasekaran, A., \& Cheng, J. (2014). Customer satisfaction and competitiveness in the Chinese E-retailing: Structural equation modeling (SEM) approach to identify the role of quality factors. Expert Systems with Applications, 41(1), 69-80.

Sun, L. (2015, October 12). Millennials love Amazon's same-day shipping. Retrieved March 20, 2019, from Business Insider: https://www.businessinsider.com/millennials-loves-amazons-same-day-shipping-2015$10 / ? \mathrm{IR}=\mathrm{T}$

Sutriyanto, E. (2018, 04 13). iSeller dan GO-SEND Hadirkan Solusi Sistem Penjualan Online dan Pengiriman Barang. $\quad$ Retrieved $01 \quad 22, \quad 2019, \quad$ from Tribun http://www.tribunnews.com/bisnis/2018/04/13/iseller-dan-go-send-hadirkan-solusi-sistem-penjualanonline-dan-pengiriman-barang

Teo, T., \& Liu, J. (2007). Consumer Trust in E-Commerce in the United States, Singapore and China. Omega Journal, 35(1), 22-38.

Tipping, A., \& Kauschke, P. (2018). Shifting patterns. London: PWC.

University of Minnesota. (2018, September 11). DATA ANALYSIS. Retrieved November 14, 2018, from https://cyfar.org/inferential-analysis

University of South Australia. (2018, November 9). Overview of statistical software packages. Retrieved November 12, 2018, from Introduction to Statistical Software: https://lo.unisa.edu.au/mod/book/view.php?id=631718

Vaalei, N., Rezaei, S., \& Shahijan, M. K. (2016). CouQual: assessing overall service quality in courier service industry and the moderating impact of age,gender and ethnicity. International Journal Management Concepts and Philosophy, 9(2), 144-169.

Wallace, D. W., Gieses, J. L., \& Johnson, J. L. (2004). Customer retailer loyalty in the context of multiple channel strategies. Journal of retailing, 80(4), 249-263.

Wang, E. S., \& Lin, R. (2016). Perceived quality factors of location-based apps on trust, perceived privacy risk and continuous usage intention. Behaviour and Information Technology, 36(2), 1-9.

Ye, Z., Abbas, H., Hussain, T., \& He, J. (2018, October 25). Analyzing The Differentiation Strategies of Big Companies Competing with Each Other. Retrieved November 16, 2018, from Researchgate: https://www.researchgate.net/publication/328327119_Analyzing_the_differentiation_strategies_of_big_c ompanies_competing_with_each_other 